This PDF is a selection from a published volume from the National Bureau of Economic Research

Volume Title: Changes in the Share of Wealth Held by Top Wealth-Holders, 1922-1956

Volume Author/Editor: Robert J. Lampman

Volume Publisher: NBER

Volume ISBN: 0-87014-385-9

Volume URL: http://www.nber.org/books/lamp60-1

Publication Date: January 1960

Publication Type: Occasional Paper no. 71

Chapter Title: Changes in the Share of Wealth Held by Top Wealth-Holders, 1922-1956

Chapter Author: Robert J. Lampman

Chapter URL: http://www.nber.org/chapters/c1733

Chapter pages in book: $(1-40)$ 


\section{Changes in the \\ Share of Wealth Held by \\ Top Wealth-Holders, \\ 1922-1956}

ROBERT J. LAMPMAN

OCCASIONAL PAPER 71

NATIONAL BUREAU OF ECONOMIC RESEARCH, INC. 1960 
Reprinted from the November 1959 issue of The Review of Economics and Statistics Harvard University, Department of Economics

Library of Congress Catalog Card Number: 59-12561

Price: $\$ 0.75$

NATIONAL BUREAU OF ECONOMIC RESEARCH, INC. 261 Madison Avenue, New York 16, N.Y. 


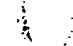




\section{NATIONAL BUREAU OF ECONOMIC RESEARCH}

\section{9}

OFFICERS

George B. Roberts, Chairman

Arthur F. Burns, President

Theodore W. Schultz, Vice-President

Murray Shields, Treasurer

Solomon Fabricant, Director of Research

Geoffrey H. Moore, Associate Director of Research

William J. Carson, Executive Director

DIRECTORS AT LARGE

Wallace J. Campbell, Director, Cooperative League of the USA Solomon Fabricant, New York University

Gabriel Hauge, Chairman, Finance Committee, Manufacturers Trust Company

Albert J. Hettinger, Jr., Lazard Frères and Company

Oswald W. Knauth, Beaufort, South Carolina

H. W. Laidler, Executive Director Emeritus, League for Industrial Democracy

Shepard Morgan, Norfolk, Connecticut

George B. Roberts, Larchmont, New York

Beardsley Ruml, New York City

Harry Scherman, Chairman, Book-of-the-Month Club

Boris Shishkin, American Federation of Labor and

Congress of Industrial Organizations

George Soule, Professor Emeritus, Bennington College

N. I. Stone, Consulting Economist

J. Raymond Walsh, New York City

Joseph H. Willits, Director, The Educational Survey, University of Pennsylvania Leo Wolman, Columbia University

Donald B. Woodward, Vick Chemical Company

Theodore O. Yntema, Vice-President-Finance, Ford Motor Company

V. W. Bladen, Toronto

DIRECTORS BY UNIVERSITY APPOINTMENT

\section{Arthur F. Burns, Columbia}

Melvin G. de Chazeau, Cornell

Frank W. Fetter, Northwestern

H. M. Groves, Wisconsin

Gottfried Haberler, Harvard
Walter W. Heller, Minnesota Maurice W. Lee, North Carolina Lloyd G. Reynolds, Yale T. W. Schultz, Chicago Jacob Viner, Princeton

Willis J. Winn, Pennsylvania

DIRECTORS APPOINTED BY OTHER ORGANIZATIONS

Percival F. Brundage, American Institute of Certified Public Accountants

Harold G. Halcrow, American Farm Economic Association

Theodore V. Houser, Committee for Economic Development

Stanley H. Ruttenberg, American Federation of Labor and

Congress of Industrial Organizations

Murray Shields, American Management Association

Willard L. Thorp, American Economic Association

W. Allen Wallis, American Statistical Association

Harold F. Williamson, Economic History Association

Moses Abramovitz

Gary S. Becker

Gerhard Bry

Arthur F. Burns

Morris A. Copeland

Frank G. Dickinson

James S. Earley

Richard A. Easterlin

Solomon Fabricant

Milton Friedman
RESEARCH STAFF

Raymond W. Goldsmith

Leo Grebler

Millard Hastay

W. Braddock Hickman

Daniel M. Holland

Thor Hultgren

C. Harry Kahn

John W. Kendrick

Simon Kuznets

Clarence D. Long
Ruth P. Mack

Ilse Mintz

Geoffrey H. Moore

Roger F. Murray

G. Warren Nutter

Lawrence H. Seltzer

Robert P. Shay

George J. Stigler

Leo Wolman

Herbert B. Woolley 


\section{Relation of the Directors}

\section{to the Work and Publications \\ of the National Bureau of Economic Research}

1. The object of the National Bureau of Economic Research is to ascertain and to present to the public important economic facts and their interpretation in a scientific and impartial manner. The Board of Directors is charged with the responsibility of ensuring that the work of the National Bureau is carried on in strict conformity with this object.

2. To this end the Board of Directors shall appoint one or more Directors of Research.

3. The Director or Directors of Research shall submit to the members of the Board, or to its Executive Committee, for their formal adoption, all specific proposals concerning researches to be instituted.

4. No report shall be published until the Director or Directors of Research shall have submitted to the Board a summary drawing attention to the character of the data and their utilization in the report, the nature and treatment of the problems involved, the main conclusions, and such other information as in their opinion would serve to determine the suitability of the report for publication in accordance with the principles of the National Bureau.

5. A copy of any manuscript proposed for publication shall also be submitted to each member of the Board. For each manuscript to be so submitted a special committee shall be appointed by the President, or at his designation by the Executive Director, consisting of three Directors selected as nearly as may be one from each general division of the Board. The names of the special manuscript committee shall be stated to each Director when the summary and report described in paragraph (4) are sent to him. It shall be the duty of each member of the committee to read the manuscript. If each member of the special committee signifies his approval within thirty days, the manuscript may be published. If each member of the special committee has not signified his approval within thirty days of the transmittal of the report and manuscript, the Director of Research shall then notify each member of the Board, requesting approval or disapproval of publication, and thirty additional days shall be granted for this purpose. The manuscript shall then not be published unless at least a majority of the entire Board and a twothirds majority of those members of the Board who shall have voted on the proposal within the time fixed for the receipt of votes on the publication proposed shall have approved.

6. No manuscript may be published, though approved by each member of the special committee, until forty-five days have elapsed from the transmittal of the summary and report. The interval is allowed for the receipt of any memorandum of dissent or reservation, together with a brief statement of his reasons, that any member may wish to express; and such memorandum of dissent or reservation shall be published with the manuscript if he so desires. Publication does not, however, imply that each member of the Board has read the manuscript, or that either members of the Board in general, or of the special committee, have passed upon its validity in every detail.

7. A copy of this resolution shall, unless otherwise determined by the Board, be printed in each copy of every National Bureau book.

(Resolution adopted October 25, 1926 and revised February 6, 1939 and February 24, 1941) 


\title{
Changes in the Share of Wealth Held by Top Wealth-holders,
}

\author{
1922-1956*
}

\author{
Robert J. Lampman
}

T

HIS paper presents estimates derived from federal estate tax data of the numbers of top wealth-holders ${ }^{1}$ and of the aggregate amounts of wealth held by them for selected years between 1922 and 1956 . Changes in the concentration of wealth during that period are delineated by relating the numbers of top wealthholders to the population and the amount of wealth held by the top group to independent estimates of the amount of wealth held by all persons.

The discussion is organized under the following headings: ( $\mathrm{r}$ ) History of Wealth Distribution Study; (2) Sources of Data and Methods

* This is part of a larger study which was carried out while the author was Research Associate at the National Bureau of Economic Research. The author has been aided by a great many persons. In particular, the study owes much to Raymond W. Goldsmith, who was instrumental to its initiation and who frequently gave counsel and encouragement to the author. The charts were drawn by $\mathbf{H}$. Irving Forman. Research assistance was provided by Elaine Saleman, Irving Brown, and Robert Ross. An earlier draft of this paper was read at the December 1958 meetings of the Econometric Society where it profited from the discussant comments of Selma F. Goldsmith and Victor Perlo. The author is also indebted to Geoffrey $H$. Moore for constructive criticism. The author is solely responsible for any errors which may remain.

This paper has been approved for publication as a report of the National Bureau of Economic Research by the Director of Research and the Board of Directors of the $\mathrm{Na}$ tional Bureau, in accordance with the resolution of the board governing National Bureau reports (see the Annual Report of the National Bureau of Economic Research). It is reprinted as No. $7 \mathrm{I}$ in the National Bureau's series of Occasional Papers.

"The term "top wealth-holder" is here defined to mean a living person having wealth in an amount above the estate tax exemption. 
of Estimation; (3) The Share of Top Wealthholders in 1953; (4) A Comparison with Survey of Consumer Finances for 1953; (5) Historical Changes in Inequality; (6) Comparison with Wealth Distribution in England and Wales; and (7) Summary.

\section{History of Wealth Distribution Study}

Studies of wealth distribution in the United States are quite rare. Up to the close of World War II only ten scholars are known to have attempted nation-wide size distributions of personally held wealth.

Several important steps in the history of wealth distribution study taken after 1945 were prerequisite to any advance in understanding which may be contributed by the present study. One was the first demonstration in this country of the use of the estate multiplier method. This pioneering work was done by Horst Mendershausen. While earlier investigations had used estate tax data, none of them had used this method to estimate the distribution of wealth among living persons. Mendershausen's study, "The Pattern of Estate Tax Wealth," ${ }^{2}$ is the platform from which this inquiry departs. A second step was the completion of a set of national balance sheet accounts for a limited number of bench-mark years. These accounts as published by Goldsmith ${ }^{3}$ show considerable detail by sectors of the economy and by type of property and make possible the calculation of the shares of several types of wealth held by the top wealth-holding groups. The balance sheet data for 1945,1949 and 1953 were prepared for use in this study by Morris Mendelson of the National Bureau of Economic Research.

${ }^{2}$ Raymond T. Goldsmith, A Study of Saving in the United States, Princeton University Press, 1956, Vol. III, Part III, 277-38I.

${ }^{8}$ Ibid., Vol. III, Part I, Tables W-9 through W-I6, 4I-57. 
A third and highly significant post-war contribution to the study of wealth distribution was made by the Survey Research Center of the University of Michigan in the carrying out of the first nation-wide sample studies of assets and net worth held by spending units. These studies were part of the Survey of Consumer Finances for the years 1950 and I953. They yield a broad picture of the distribution of the national total of most kinds of property and it is to be hoped that they will continue to be made and published at frequent intervals as the basic source of information on wealth distribution.

From the point of view of this study, the Survey of Consumer Finances has a special usefulness. It provides an independently arrived at set of estimates for 1953 against which our findings for 1953 can be checked for accuracy, and thus furnish us with a kind of anchor for the historical series.

\section{Sources of Data and Methods of Estimation}

The principal source of data upon which this study is based is tabulations of federal estate $\operatorname{tax}$ returns. The federal estate tax has been in existence since I 9 I 6 and some information on returns filed has been published for most years. The minimum filing requirement, which is currently $\$ 60,000$, has varied from $\$ 40,000$ to $\$ 100,000$ over the period. However, the necessary information concerning age and sex of decedents, cross-classified by type of property, is presented in such a way as to enable the derivation of a detailed representation of the distribution of wealth among living persons for relatively few years. For 1953 the Internal Revenue Service made available to the National Bureau of Economic Research the most complete tabulation of estate tax returns which has ever been prepared. In this tabulation the variables of gross estate size, age, sex, and residence (by community-property state or non-commu- 
nity-property state) of decedents were crossclassified by type of property. For the year 1944 a similar breakdown, but without sex or residence information, had been prepared by the Internal Revenue Service and was the basis for the intensive study by Horst Mendershausen referred to above. For 1948, 1949 and 1950 there is information by age and gross estate size which makes possible an estimate of aggregate gross estate without a breakdown by type of property. Similar but unpublished data for r 94 I and r 946 were made available to Mendershausen. Data on economic estate by net estate size and age are available for 1922,1924 , r94 I, I944 and r946. Finally, data on the sex of decedents by age and size of estate are available only for the years 1922, 1923, 1948, 1949, I950 and 1953 .

The method which was followed in dealing with estate tax returns is known as the estate multiplier method. This method calls for multiplying both the number of, and the property of, decedents in each age-sex group by the inverse of the mortality rate experienced by that age-sex group. This process yields an estimate of the number of living persons and the amount of estate in each age-sex group and in each estate size class. A simple hypothetical example will illustrate what is involved. Suppose that out of a population of $I, 000$ men aged 40 to 50 , 2 men died in the year with estates of between $\$ 100,000$ and $\$ 200,000$. Suppose further that it is known that 5 per cent of all the 1,000 men aged 40 to 50 died in the year. Then it may be assumed that the 2 men who died with $\$ 100,000-$ $\$ 200,000$ estates were 5 per cent of all the living men in the group with estates of this size. Hence, to estimate the number of living men in this estate size class we should multiply 2 by 20 (the inverse of 5 per cent) to get the answer of 40 living men having $\$ 100,000-\$ 200,000$ estates.

The leading disadvantage of thus deriving 
wealth estimates from estate tax returns arises from the fact that the "sampling" is done by death rather than by a random draw of living persons. This means that a connection can be established between decedent wealth-holders and living wealth-holders only by use of a set of mortality rates which are assumed to reflect the mortality experience of the upper wealthholding groups. The selection of mortality rates presents an opportunity for considerable error in the estimation of the number of living persons in each estate size, and, similarly, in the aggregate of wealth held by such persons. Other problems arise to the extent that decedents' reported estates may differ from the "actual" estates of non-decedents in the same age-sex groups.

Space here does not allow a full exploration of these two difficulties. However, we have attempted to find the most appropriate set of multipliers for this purpose, and have examined in detail the peculiarities of the method of sampling by estate tax returns. We have estimated quantitative corrections in those instances in which by law or practice individual wealth items are included, excluded, or differently valued than an ideal definition of personal wealth would require. In the course of the inquiry two ideal definitions were improvised. "Prime wealth" is used to connote the wealth to which a person has full title and over which he has power of disposal. "Total wealth" is a broader concept; it includes prime wealth and also wealth in which a person may have an income interest but over which he may not have any present power of disposal. Examples of the latter are rights to personal trust funds or to equities in pension and retirement funds. Our rough estimates indicate that basic variant aggregate estimates (which are the blown-up estate tax data with only one correction, namely that for reduction of insurance face value to 
equity amounts) are not substantially different from an ideally arrived at estimate of prime wealth, but are considerably lower than the aggregate of total wealth.

Share of Top Wealth-holders in 1953

In 1953 there were 36,699 decedents for whom estate tax returns were filed. The aggregate gross estate reported on those returns was $\$ 7.4$ billion. By use of the estate multiplier method it is estimated that the number of living persons in that year with $\$ 60,000$ or more of gross estate was $I, 658,795$ and that their gross estates aggregated $\$ 309.2$ billion. This number of persons comprised r.04 per cent of the total population and $\mathrm{r} .6$ per cent of the adult population. They held about 30 per cent of the total of personal wealth on the basis of either the prime wealth or total wealth variant of personal wealth. See Chart I and Table I. Table I ${ }^{4}$ needs some

Chart i. - Share of Personal Sector Equity (Prime Wealth Vartant) Held by Top Wealth Holders, I953.

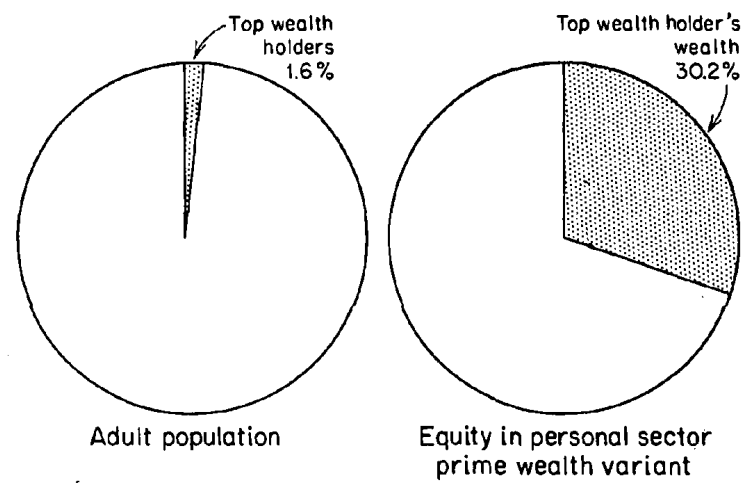

Source: Table I, column 12.

explanation. The data in Columns $\mathrm{I}-7$ are derived from the national balance sheet accounts

- Similar tables have been drawn up for 1949, I945, 1939, I929, and r922 but are not reproduced here. 
referred to above. These accounts record estimates of aggregate assets, liabilities, and equities for sectors of the economy. Several of these sectors have been combined and adjusted to form a "personal sector" which is conceptually adapted for comparison with the holdings of individual wealth-holders. As shown in Table I the personal sector is defined to include the following subsectors: "household," "farm business," and "nonfarm, noncorporate" and "personal trust funds." (We have excluded nonprofit organizations entirely.)

Since the household subsector consolidates balance sheets of all households, the debts owed by one household to another are cancelled out. -In other words, intra-household debt is excluded both as an asset and as a liability. Another difficulty arises in the treatment of households' equity in unincorporated business. Because the national balance sheets do not consolidate the household, farm business, and nonfarm business subsectors while the estate tax wealth data in effect do consolidate them ${ }^{5}$ the balance sheet totals for most types of property are relatively over-stated. This means that we do not have strict comparability on a line-by-line basis, but it is believed that this is not a serious difficulty for most types of property. Double-counting of the equity in unincorporated business is avoided by showing it in the household sector but not adding it into the personal sector totals. Hence, this does not lead to any errors in the total gross and economic estate figures. Following the concepts discussed above, we refer to prime wealth and total wealth variants of personal wealth. Prime wealth differs from total wealth in that prime wealth excludes personal trust funds, annuities, and pension and retirement funds.

${ }^{5}$ That is, estate tax wealth is not uniformly classified to show all assets held by unincorporated enterprises as "equity in unincorporated business." In some cases they are separately listed as real estate, cash, etc. The equity item is listed under the heading of miscellaneous in Table $r$. 


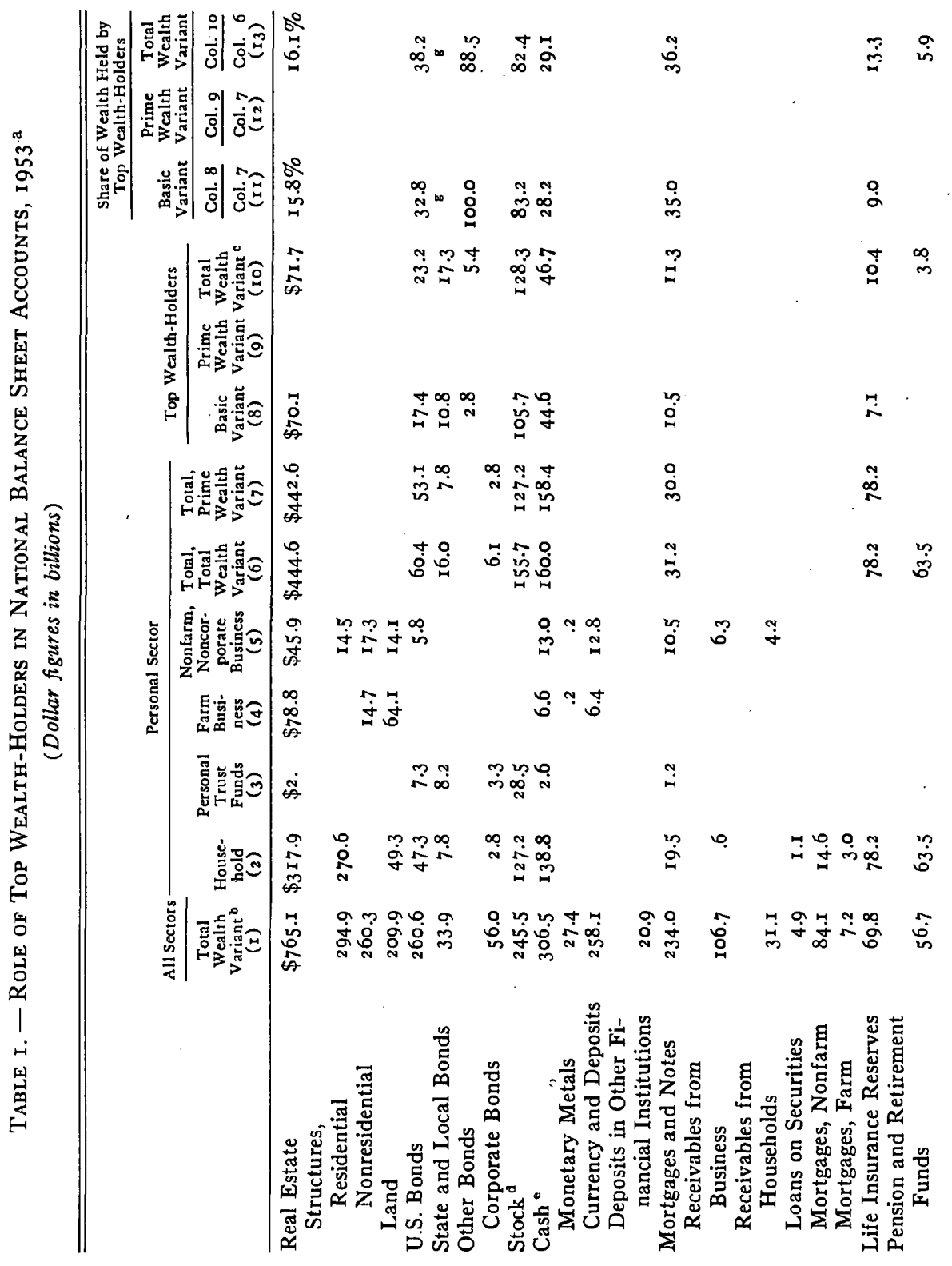




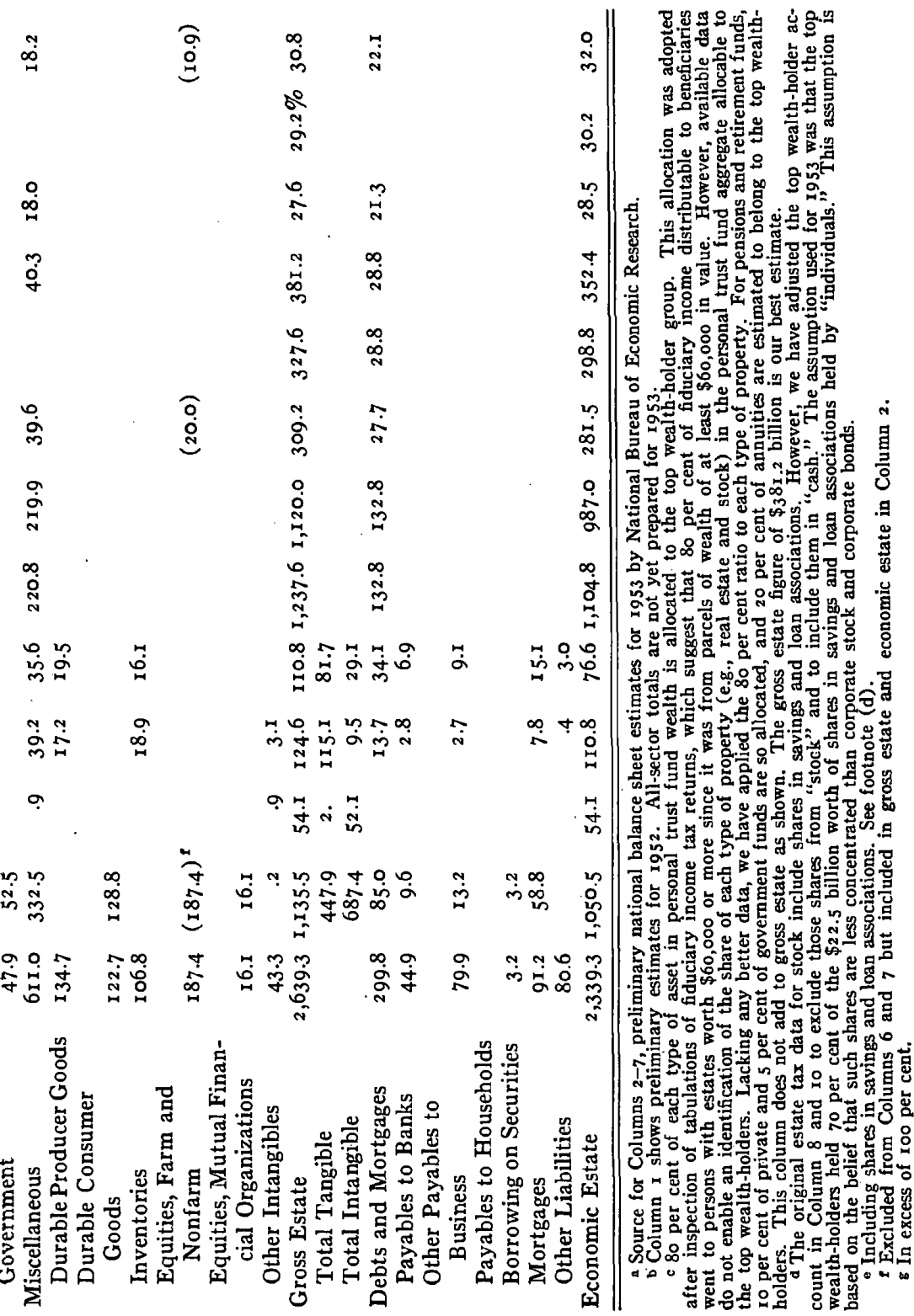


The top wealth-holders, i.e., those with estates of $\$ 60,000$ or more, in I 953 held 30.2 per cent of the prime wealth in the personal sector, and 32.0 per cent of the total wealth. (See Table I, Columns I 2 and I 3 .) These columns also show estimates of the share of each of several types of property held by top wealth-holders. These range from over roo per cent for state and local bonds down to 9 per cent for life insurance reserves. Particular interest attaches to the corporate stock figure. Our estimate for I 953 is that the top wealth group held 82 per cent of all the stock in the personal sector. This matter is discussed in more detail below in the section on type of property.

Comparison with S.C.F. Findings, 1953

The broadest view obtainable of the wealth holdings picture in 1953 is that furnished by the Survey of Consumer Finances for that year. According to the survey the median net worth of the nation's 54 million spending units was $\$ 4$, IOo. Four per cent of the nation's spending units had net worth of $\$ 50,000$ or more. Eleven per cent had net worth of $\$ 25,000$ or more. This upper I I per cent held 56 per cent of total assets and 60 per cent of total net worth. While this group held only 30 per cent of consumer capital goods, they held 80 per cent of business and investment assets. (See Table 2.)

Inspection of 1953 Survey results suggests that the spending units having $\$ 60,000$ or more of net worth were 3 per cent of all spending units in 1953. These spending units held 30 per cent of total assets and 32 per cent of total net worth. ${ }^{6}$ These particular figures about the top 3 per cent are ones we would like to compare with the estimates of the holdings of top wealth-holding individuals as made via the estate multiplier method.

\footnotetext{
${ }^{\theta}$ It is of interest that the Survey conclusions about this top group are based upon interviews with ${ }_{2} 4$ spending units.
} 
First, however, it should be noted that there are some limitations to the 1953 Survey data as a representation of wealth-holdings. Not all types of property were included in the count. Insurance, consumer durables other than automobiles, currency, personal trust funds, annuities, pension reserves, bonds of corporations and of state, local and foreign governments were all omitted. Further, there appears to be some understatement of those assets which were included, with perhaps the largest understatement for liquid assets. ${ }^{7}$ These exclusions and the

Table 2.- Proportion of Net Worth and Components Held Within Net Worth Groups, Early $1953^{\mathrm{a}}$

\begin{tabular}{|c|c|c|c|c|c|c|c|c|}
\hline $\begin{array}{l}\mathbf{3} \\
\vdots \\
\vdots \\
\vdots \\
\mathbf{y} \\
z\end{array}$ & 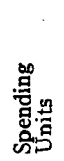 & 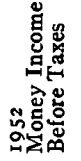 & 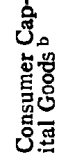 & 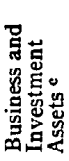 & 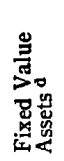 & 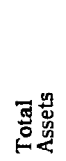 & $\begin{array}{l}\stackrel{\leftrightarrow}{*} \\
\text { ڤ̆ }\end{array}$ & 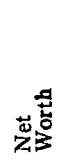 \\
\hline \multicolumn{9}{|c|}{ Per Cent } \\
\hline Negative & 31 & & I & $\left({ }^{t}\right)$ & ${ }^{(t)}$ & (I) & 6 & $(\mathrm{~g}$ \\
\hline $0-\$ 999$ & 31 & & $\mathbf{I}$ & $\left({ }^{t}\right)$ & 2 & $\mathbf{I}$ & 4 & 1 \\
\hline$\$ 1,000-\$ 4,999$ & 23 & 20 & 13 & I & 9 & 7 & 18 & 5 \\
\hline$\$ 5,000-\$ 24,999$ & 35 & 37 & 55 & I9 & 37 & 36 & $5 I$ & 34 \\
\hline$\$ 25,000$ and over & II & 24 & 30 & 80 & $5^{2}$ & 56 & $2 I$ & 60 \\
\hline All Cases & 100 & 100 & 100 & 100 & 100 & 100 & 100 & 100 \\
\hline
\end{tabular}

Aggregation

$\begin{array}{lllllllll}\text { Valuation } & \ldots & 219 & 288 & 328 & 109 & 725 & 84 & 64 \mathrm{I}\end{array}$

a Source: 1953 Survey of Consumer Finances, Reprinted from Federal Reserve Bulletin, 1953, supplementary Table 5, p. 1x.

Includes automobiles and owner-occupied nonfarm houses.

c Includes owner-occupied farms, farm machinery, livestock, crops, interest in unincorporated business, and privately held corporations, real estate other than home or farm on which owner is living, and corporate stock.

d Includes liquid assets and loans made by spending units.

- Includes mortgages and other real estate debt, installment and other short-term debt.

1 Less than one-half of I per cent.

g Negative or less than one-half of one per cent.

${ }^{2}$ Approximately 80 to 85 per cent of the full value of the included items is accounted for by the Survey. Among the excluded items, personal trust funds, annuities, and pension reserves, which together totalled about $\$ 100$ billion, fall outside our definition of prime wealth. For a comparison of Survey and national balance sheet aggregates, see Goldsmith's A Study of Saving, vol. III, I07, Table W-44. Further diffculties with Survey data are discussed in the Federal Reserve Bulletin, September I958, I,047. 
difficulty of getting full representation of top wealth-holders and complete reporting of their holdings would lead one to suspect that the Survey has probably understated the degree of inequality of wealth distribution on a prime wealth basis and more certainly on a total wealth basis.

Since all our estate tax data are for individuals, it is awkward to check them against the spending unit estimates of the Survey. This study shows that while the top wealth-holder group in r953 made up r.6 per cent of all adults, they represented a minimum of 2.3 per cent of the families. More precisely, in 2.3 per cent of the families there was one or more person with $\$ 60,000$ or more of gross estate. In some unknown number of other families the combined holdings of two or more persons.' will equal $\$ 60,000$ or more. In the light of this the Survey's estimate that 3 per cent of the spending units have $\$ 60,000$ or more of net worth seems altogether reasonable. Similarly, their estimate that this group had 30 per cent of total assets and $3^{2}$ per cent of total net worth seems compatible with our findings that the top 1.6 per cent of adults held 30.2 per cent of total economic estate. To add another .7 per cent of all families would mean to add another 400,000 persons to the top wealth-holder group. If we impute $\$ 60,000$ to each one of them this would add $\$ 24$ billion or an extra two percentage points to the top group's share of total economic estate. 30.2 plus 2 equals 32.2 which is close to the Survey's finding of 32 per cent of net worth. In spite of the fact that the Survey figures tend to minimize the degree of inequality by exclusions of certain kinds of property, we find only slightly more inequality than is found by the Survey. However, the principal conclusion is that the Survey gives some confirmation to our estimates at one end of the historical series. 


\section{Historical Changes in Inequality ${ }^{8}$}

Table I and unpublished companion tables enable a comparison of top wealth-holders and the personal sector for the years 1953, 1949, 1945, 1939, 1929, and 1922. In looking for trends over the decades the reader should remember that varying numbers of wealth-holders are involved in each year. These changes are due to changing exemption limits, changing prices and incomes; and changing population numbers. Chart 2 records the changing number

\footnotetext{
${ }^{8}$ So far as is known, this is the first attempt to relate estate tax data to national balance sheet aggregates. Several other students of wealth distribution have examined changes in concentration within the group of decedent estate tax wealth-holders. W. L. Crum studied the returns for the period I9I6-I933 and concluded that "with respect to curvature, as with respect to the coefficients of average inequality, a rough lagging correlation with the economic cycle is evident. Prosperity is followed by a much greater stretching into high total valuations of the few largest estates than is depression." (The Distribution of Wealth, Boston, Harvard University Graduate School of Business, I935, 10).

Working from a distribution of estate tax returns by net estate classes, Mendershausen was able to make some comparisons of inequality among living top wealth-holders for the I 920 's and the I 940 's. He concludes as follows:

". . . we find less inequality in the 1944 and 1946 distributions than in those for 1922 and 1924 . This pertains of course to all returns for each of the several years, which, as has been noted before, extended over a changing range of wealth classes owing to changes in exemptions" (p. 344). These exemptions were $\$ 50,000$ in 1922 and 1924 , and $\$ 60,000$ in the 1940 's.

The introduction of the marital deduction in 1948 makes the net estate data after that year noncomparable with that for earlier years. Hence, we cannot compare the inequality among top wealth-holders in the 1920's and 1940's with the I950's. It is possible to compare the distribution of gross estate among the top wealth-holders in 1944 and 1953 . We find virtually no difference in inequality in the two years. It should be emphasized that there is great difficulty in the way of presenting a meaningful comparison of the degree of inequality among estate-tax wealth-holders over the years. Because of the dollar exemption (which itself changes) and the changing level of asset prices and the general growth in the economy, the top wealth-holders constitute a varying proportion of the total population. To compare the inequality within a group whose limits are so arbitrary and whose relative importance is so variable is apt to raise more questions than it answers.
} 
of top wealth-holders and the changing population between 1922 and 1953 .

Comparison over the years, at least as regards aggregate economic estate, is facilitated by Table 3 . Here we have shown as much information as could be assembled for the years 1922-1956. In some cases the results are the product of interpolation. The estimates shown for 1929,1933 , I939 and 1954 and 1956 are particularly contrived, since the estate tax data for those years are not presented with age and estate size breakdowns and it has been necessary to use judgment in selecting devolution rates $^{9}$ for those years. The 1945 results are adjusted on the basis of 1944 findings, for which considerable basic data were available.

In columns $14-18$ the proportion that estate tax wealth-holders are of the total population is shown with their share of total wealth. Thus, in 19220.47 per cent of the population held 29.2 per cent of the total equity of the personal sector. In 19490.80 per cent of the population held 22.7 per cent of the total equity. In 1953 r.04 per cent of the population held 28.5 per cent of the total equity. The whole set of figures suggests a downward drift in the degree of concentration of wealth, particularly from 1929 to I945. I 929 stands out as the peak year for inequality in this series with 0.27 per cent of the population holding 29.0 per cent of the wealth. There is considerable variability in these relationships over short periods. The variability may be due to sampling errors or other errors in the estate tax wealth estimates or to difficulties in the National Balance Sheet estimates or to a combination of such errors. On the other hand, it is not altogether implausible that the degree of inequality would have increased during the 1920's, returned to below the pre-I929 level in the I930's, fallen still

${ }^{\circ}$ A devolution rate is an average estate multiplier for number of persons or amount of estate. 
more during the war and then increased from I 949 to 1956.

Table 4 summarizes, perhaps in a clearer way, what changes in inequality are estimated. ${ }^{10}$ It shows the same top per cent of population in

\section{Chart 2. - Top Wealth-Holders and the Adult Population, Selected Years, 1922 2-I953}

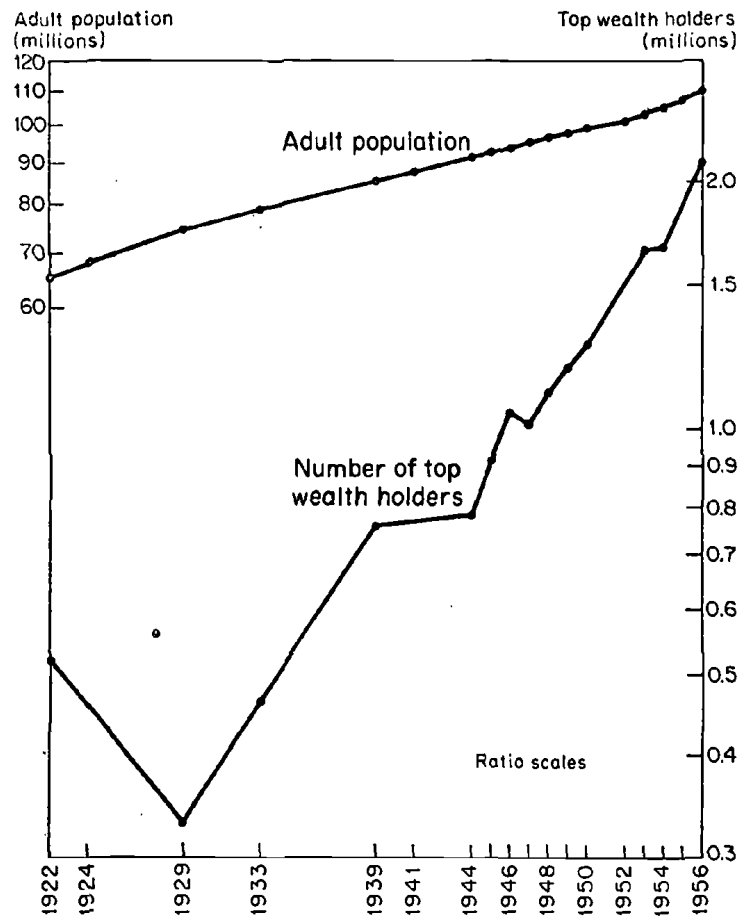

Nore: As it is defined in the text a "top wealth-holder" is a living person having wealth in an amount above estate tax exemption level. The sharp drop in number of top wealth-holders in 1929 was due to the extraordinarily high estate tax exemption of $\$ 100,000$ effective in that year.

Sounce: Table 3 .

I953 as the total group of estate tax wealthholders were in some earlier years. Thus, in I 922 the estate tax wealth-holders comprised 0.47 per cent of the total population and held 29.2 per cent of the wealth. In 1953 the top 0.47 per cent held 22.0 per cent of the wealth.

${ }^{10}$ This section has been much improved by the suggestions of Thor Hultgren. 


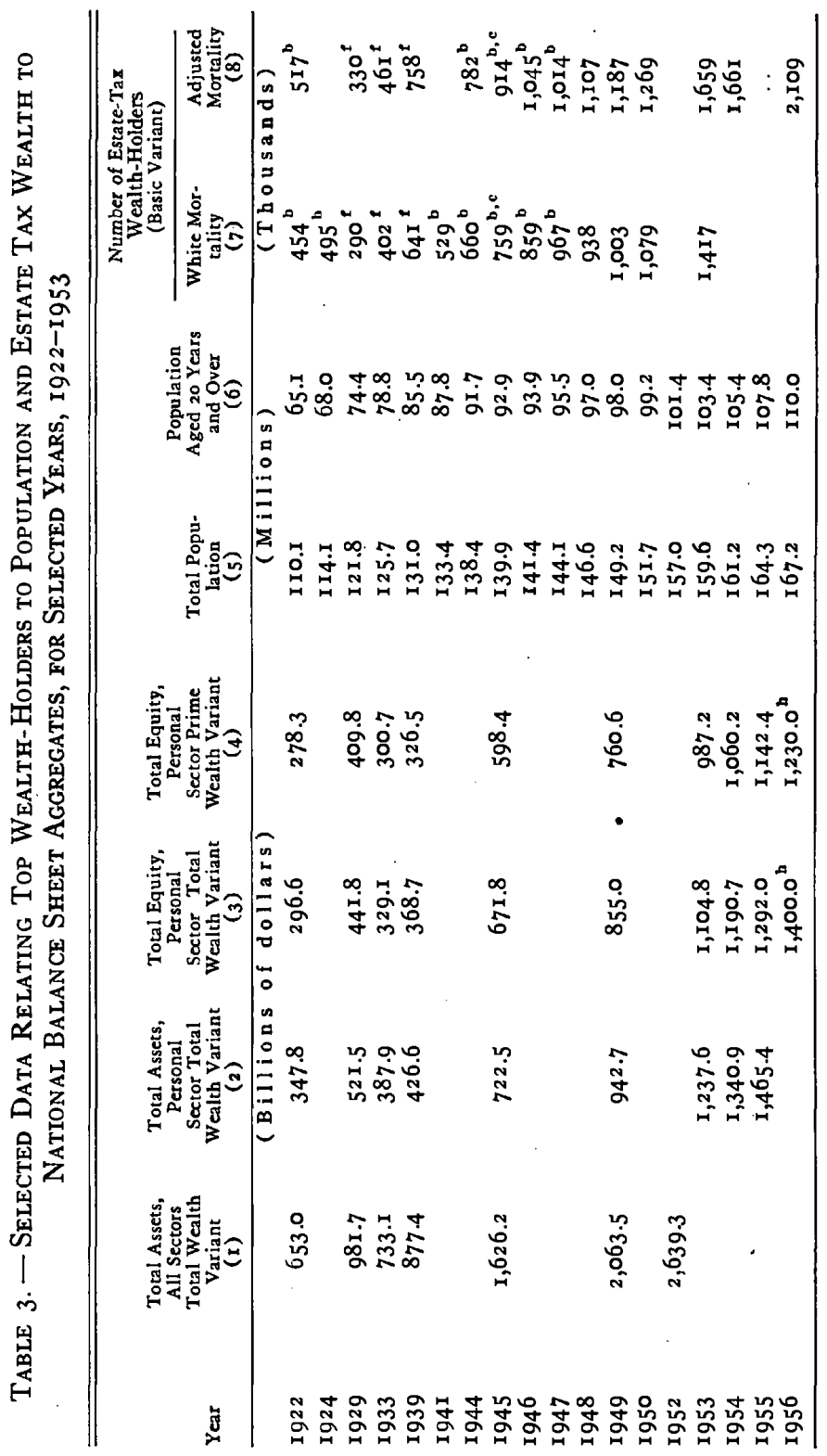




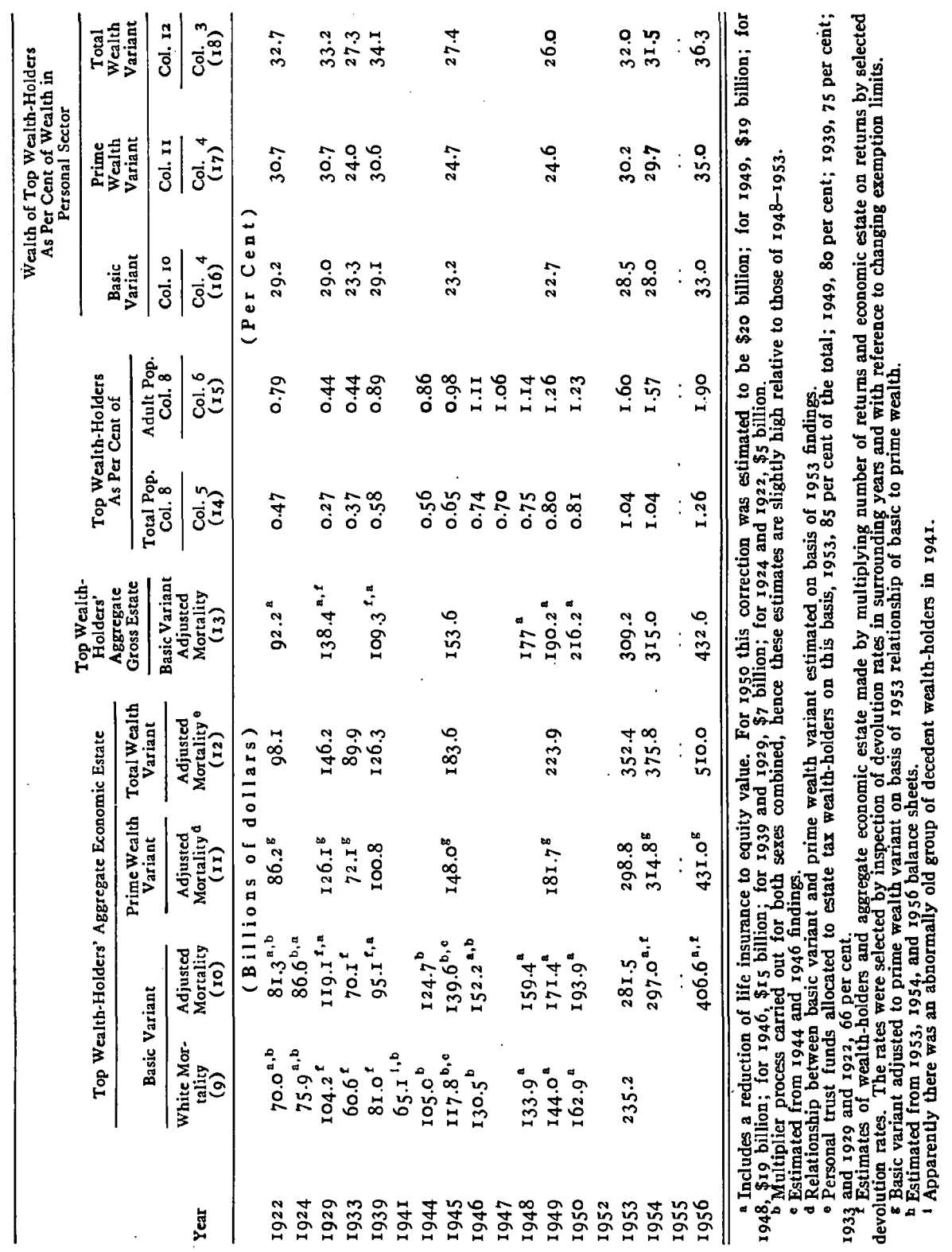


This is shown graphically in Chart 3, which shows the upper right-hand section of a Lorenz curve. ${ }^{11}$ The easiest way to see what changes are involved is to hold the per cent of population constant, which can be done with minimum guessing only for the top one-half per cent of the population for the series of years. (See bottom row in Table 4.) This shows quite clearly that there were three periods with inequality declining in jumps from the 1920's to

Table 4. - Share of Top Groups of Wealth-Holders Shown as Per Cent of Total Population in Personal Sector Total Equity (Bastc Variant) SeLECTED YEARS, I92 2-I 953

\begin{tabular}{rccccccccc}
\hline $\begin{array}{c}\text { Per Cent of } \\
\text { Population }\end{array}$ & 1922 & 1929 & 1933 & 1939 & 1945 & r949 & 1953 & 1954 & 1956 \\
\hline \multicolumn{8}{c}{ Per Cent of Wealth } \\
Top 0.27 & $\ldots$ & 29.0 & $\ldots$ & $\ldots$ & 16.9 & $\ldots$ & 18.0 & \\
0.37 & $\ldots$ & $\ldots$ & 23.3 & $\ldots$ & 18.6 & $\ldots$ & 20.2 & & \\
0.47 & 29.2 & $\ldots$ & $\ldots$ & $\ldots$ & 20.2 & $\ldots$ & 22.0 & & \\
0.58 & $\ldots$ & $\ldots$ & $\ldots$ & 29.1 & 21.8 & $\ldots$ & 23.8 & & \\
0.65 & $\ldots$ & $\ldots$ & $\ldots$ & $\ldots$ & 23.2 & $\ldots$ & 24.8 & & \\
0.80 & $\ldots$ & $\ldots$ & $\ldots$ & $\ldots$ & $\ldots$ & 22.7 & 26.6 & & \\
1.04 & $\ldots$ & $\ldots$ & $\ldots$ & $\ldots$ & $\ldots$ & $\ldots$ & 28.5 & 28.0 & \\
1.26 & $\ldots$ & $\ldots$ & $\ldots$ & $\ldots$ & $\ldots$ & $\ldots$ & $\ldots$ & $\ldots$ & 33.0 \\
Top 0.50 & 29.8 & 32.4 & 25.2 & 28.0 & 20.9 & 19.3 & 22.7 & 22.5 & 25.0 \\
\hline \hline
\end{tabular}

Source: Table 3 , columns 14 and 16 . Percentages for top 0.5 per cent of population, shown in last row above are derived from Chart 3 by extension of lines from known points. The extensions were made by drawing lines parallel to that for 1953 , except for 1945 , for which detail is available for the top .65 per cent.

the 1930's, and then to the war and postwar periods.

The change in inequality over time is modified somewhat by considering the per cent that estate tax wealth-holders are of adults rather than of the total population. In 1920 persons

"11 This chart should be read downward and to the left from the upper right hand corner. The line of equality shows the relationship that would obtain if the top I per cent of the population held I per cent of the wealth. It will be noted that the farther a line is from the line of equality the more the inequality being represented. According to this chart the share of wealth held by the top one-half per cent moved from 1929 to 1953 about one-third of the distance toward absolute equality. 
Chart 3. - Upper Sections of Lorenz Curves Showing Share of Personal Sector Equity (Basic Variant) Held by Upper Percentiles of the Total Population for Selected Years, I922-I 953

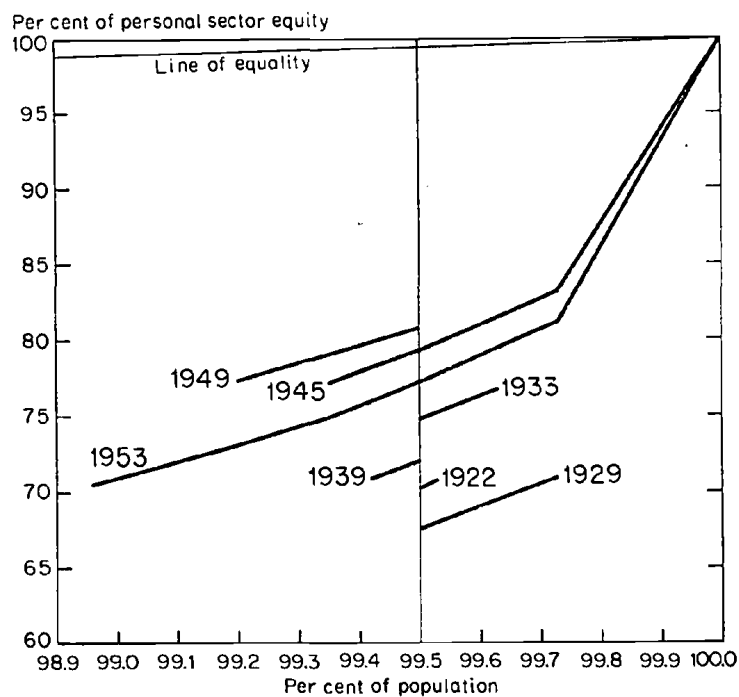

Source: Table 3.

over 20 years were 57.9 per cent of the total population; in 1930, 61.1; in 1940, 65.9; in 1950, 65.7 per cent; and in $1955,63.8$. In view of this striking change, and also because adulthood is relevant to wealth-holding status, we have shown the percentage that estate tax wealth-holders were of the adult population in column 15 of Table 3. While the share of wealth held by the top 0.5 per cent of all persons fell from 32.4 in 1929 to 22.7 per cent in 1953 (Table 4), the share held by the top 0.44 per cent of adults had a slightly larger percentage fall from 29.0 to 19.7 per cent (Table 5). The fact that there were more children, most of whom held zero wealth, per roo of population in the 1920's than in I 953 means that the top one per cent of adults were a larger part of the total population in 1953 than in 1922 . Further, it means that to include the top one per cent of adults in 1953 one has to count down to smaller 
Chart 4. - Sections of Lorenz Curves Showing Share of Personal Sector Equity (Basic Variant) Held by Upper Percentiles of the Adult PopulaTION FOR SELECTEd YeARS, I922-I953

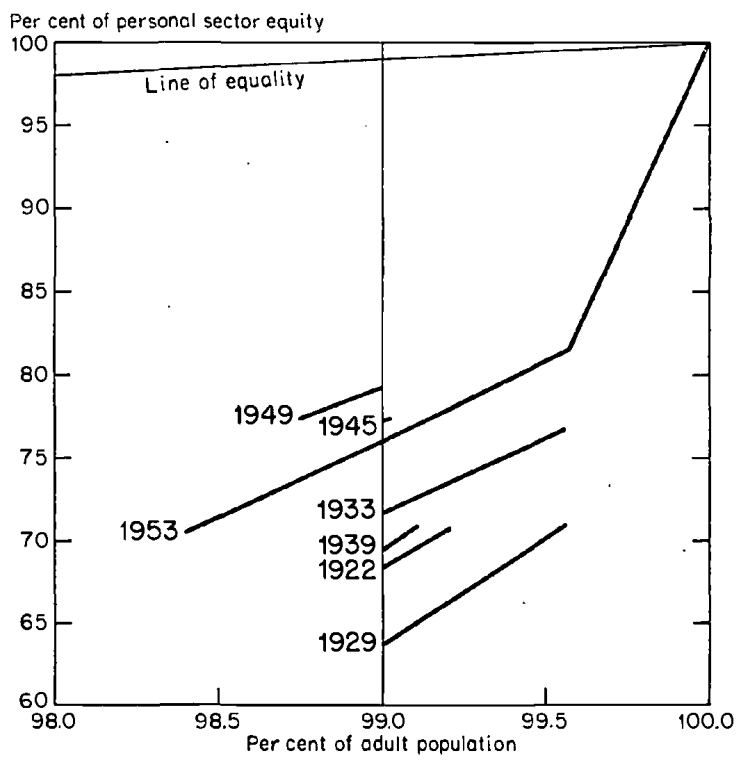

Source: Table 3 .

estate sizes than in 1922. Presumably it is because of this that we find a greater loss of share on an adult than on an all-person basis. The share of the top one per cent of adults shows a greater fall over the years than does the share of wealth of the top one-half per cent of all persons. ${ }^{12}$ The top one per cent of adults held 3 I.6 per cent of wealth in 1922 and 23.6 per

${ }^{12}$ A comment by P. F. Brundage to the author makes it clear that one may make a further step here to say that a statistical determinant of the degree of inequality of wealthholding is the age-composition of the population. Increasing the percentage that adults are of the total population tends to decrease the degree of inequality, or to offset a rise in inequality. Similarly, increasing the percentage that olderaged adults are of the total population would tend toward a showing of decreasing inequality. The reasoning runs like this: there is, in general, a positive association between age and size of estate. Hence, up to a point, as a larger part of the population moves into older age groups, the per cent of the total population with no wealth or with small estates will fall and hence the degree of inequality will fall. 
Table 5.- Share of Top Groups of Wealth-Holders (Shown as Per Cent of Total adult Population) in Personal Sector Total Equity (Basic Variant), SeleCted Years, I922-I953.

\begin{tabular}{|c|c|c|c|c|c|c|c|c|c|}
\hline $\begin{array}{l}\text { Per Cent of } \\
\text { Population } \\
\text { Aged } 20 \text { Years } \\
\text { and Over }\end{array}$ & 1922 & 1929 & I933 & 1939 & I 945 & 1949 & 1953 & 1954 & I956 \\
\hline Top 0.44 & & 29.0 & 23.3 & & & & I8.7 & & \\
\hline 0.79 & 29.2 & & & & & & 22.0 & & \\
\hline 0.89 & & & & 29.1 & & & 22.9 & & \\
\hline 0.98 & & & & & 22.9 & & 23.5 & & \\
\hline 1.26 & & & & & & 22.7 & 25.9 & & \\
\hline I. 57 & & & & & & & 28.0 & & \\
\hline 1.60 & & & & & & & 28.5 & & \\
\hline 1.90 & & & & & & & . & & 33.0 \\
\hline Top I.00 & 31.6 & 36.3 & 28.3 & 30.6 & 22.8 & 20.8 & 23.6 & 23.6 & 26.0 \\
\hline
\end{tabular}

Source: Table 3 , columns 15 and 16 . Percentages for top one per cent of adults, shown in last row above, are derived from Chart 4 by extension of lines from known points except for 1953.

cent in 1953. (See Table 5, bottom row, and Chart 4.)

Evaluation of the finding that inequality among all persons and among all adults has fallen over the period 1922 to 1953 is aided by moving to the family as the wealth-holding unit. The nearest that estate tax data enable us to come to a family wealth distribution is a rough count of the number of families having at least one member with at least $\$ 60,000$. This was established by subtracting the number of married women from the total of top wealthholders. Thus, for 1953 the total of 1.6 million top wealth-holders less the .3 million married women yields the minimum estimate of $1.3 \mathrm{mil}-$ lion families. The identical calculation for 1922 is 517,000 top wealth-holders less 45,000 married women, which yields the minimum estimate of 472,000 families. ${ }^{13}$

Setting these numbers of families among top wealth-holders against the numbers of total

${ }^{18}$ Married women were 9.7 per cent of decedent estate tax wealth-holders in 1953 , but only 5.5 per cent in 1922 . (5.3 and 6.0 per cent in 1923 and 1924.) In the estimate of living top wealth-holders married women are 18 per cent in I 953 and 8.5 per cent in 1922 . 
adults less married women in the total population yields the finding that families among the top wealth-holder group were $\mathrm{I} .4$ per cent of all families in $1922^{14}$ and 2.0 per cent of all families in 1953. Since the top wealth-holder groups in the two years held almost the same share of total equity (29.2 per cent and 28.5 per cent, respectively), it follows that the reduction in inequality is shown by the increase in the percentage of families. ${ }^{15}$ By plotting these points on a Lorenz curve and projecting the lines a short distance we estimate that the top 2 per cent of families in the two years had 33 per cent of all wealth in 1922 and 29 per cent in I953. It is apparent that a considerably greater amount of splitting of estates between

${ }^{14} \mathrm{~W}$. I. King estimated that in $192 \mathrm{I}$ the top 2 per cent of property owners held 40.19 per cent of all wealth. The top r.54 per cent held 37.25 per cent of wealth; the top 0.63 per cent held 28.14 per cent of wealth. This may be compared with our finding that in 1922 roughly the top 1.4 per cent of families held 29.2 per cent of wealth. Since some families include two or more property owners, it is probable that there would be more concentration among families than among property owners. Hence, it appears that King, by his entirely different methods, found a higher degree of inequality in wealth-holding than we do for the same period. ("Wealth Distribution in the Continental United States," Journal of the American Statistical Association, January I927, I52.)

It is also of interest that both G. K. Holmes and C. B. Spahr concluded that the top I per cent of families in I 890 owned 5 i per cent of wealth. (For Holmes' work see "The Concentration of Wealth," Political Science Quarterly, VIII, 1893, 589-600. Spahr's estimates are reported in his book, The Present Distribution of Wealth in the United States, Crowell, I896.) It is difficult to believe that wealth was actually that highly concentrated in 1890 in view of the 1921 and 1922 measures.

${ }^{15}$ Using the Census definition of "households" yields the even smaller change of from 1.9 per cent in 1922 to 2.3 per cent in 1953. However, this overlooks an important change in household size over the years. In the 1920's households included many more sub-families than was the case in any period since. (In Ig10 23 per cent of persons were heads of households; in 1950, 29 per cent were heads of households. Paul Glick, American Families, Wiley, 1957, II.) To get around this difficulty it seemed best to adopt the "adults less married females" concept referred to above as the family measure. 
spouses was being practiced in 1953 than in I922 since the percentage of adults who were top wealth-holders doubled while the percentage of families with a top wealth-holder increased only 40 per cent. (See Table 6 and Chart 5.)

Table 6. - Selected Data on Top Wealth-Holders, I 922 AND 1953

\begin{tabular}{lcccc}
\hline \hline & $\begin{array}{c}\text { Top Wealth- } \\
\text { Holders' } \\
\text { Share of Total } \\
\text { Personal } \\
\text { Equity }\end{array}$ & \multicolumn{3}{c}{ Top Wealth-Holders } \\
\cline { 3 - 5 } Year & $\begin{array}{c}\text { As Per Cent of } \\
\text { All Persons }\end{array}$ & $\begin{array}{c}\text { As Per Cent of } \\
\text { All Adults }\end{array}$ & $\begin{array}{c}\text { As Per Cent of } \\
\text { All Families }\end{array}$ \\
\hline $\mathbf{1 9 2 2}$ & 29.2 & 0.47 & 0.79 & $\mathbf{I . 4}$ \\
$\mathrm{I953}$ & 28.5 & $\mathrm{I.04}$ & $\mathrm{I.68}$ & 2.0 \\
\hline \hline
\end{tabular}

It is concluded, then, that the decline in inequality shown on the basis of individuals tends to be an overstatement of the decline which would be found on a family basis.

Another way to test whether we have really found a decline in inequality or not is to enter a question about how much error there would have to be in the balance sheet estimates upon which all the percentage estimates of wealthholdings are based in order to invalidate our finding of a decline. Suppose the balance sheet estimates of personal sector total equity are ro per cent too high in 1953 and ro per cent too low in 1922 . Correction for this assumed error (in the direction unfavorable to the hypothesis that there was a decline in inequality) yields the result that instead of the top wealth-holders having 29.2 per cent of total equity in 1922 and 28.5 per cent in r953, they would have 26 per cent in 1922 and 32 per cent in r953. Plotting these points on Chart 4 will indicate that both points could very well lie on the same Lorenz curve and hence that no decline in inequality actually took place. In this writer's judgment there is little likelihood of an error of this size.

Interestingly, the conclusions about changes over the years are not affected by selection of 
one or another variant of wealth. The gap between prime wealth and total wealth as here defined changed very little in the thirty year

Chart 5. - Share of Personal Sector Wealth (EquiTY, BaSic Variant) HeId by TOP Wealth-Holders, SeleCted YeARS, I92 2-I 953

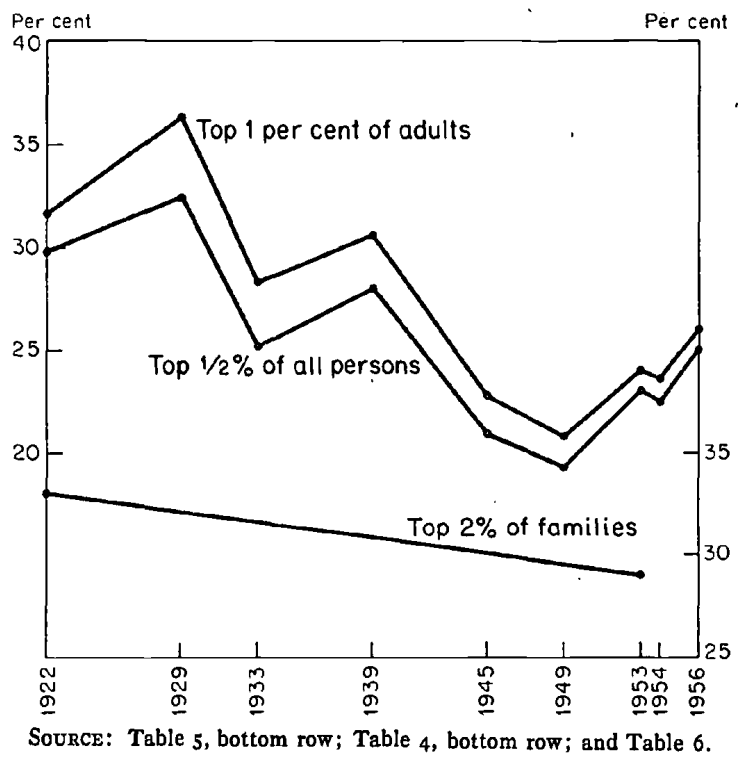

period. (See Table 3, columns I6, I 7 and I8.) A more significant difference may be involved in the choice of mortality rates. The findings shown in Table 6 are based on our adjusted mortality rates, calculated as constant percentages of white rates for the respective years. However, it is generally believed that social and economic differentials in mortality have narrowed over time and to the extent that such narrowing has taken place, we have understated the decline in inequality between 1922 and 1953 . This means the multipliers used for 1922 are too low because the mortality rates are too high. The maximum possible error here is suggested by a comparison of the results for 1922 using the adjusted mortality rates with the results for I953 using white mortality rates., Estimates of 
numbers of top wealth-holders using white mortality rates are shown in Table 3 , column 7 . The 1922 result of the top 0.47 per cent of the population holding 29.2 per cent of the wealth then compares with the top 0.88 per cent of the population in $\mathrm{I} 953$ ( $\mathrm{r} .4$ million top wealth-holders) holding 24.6 per cent of the wealth. This means that the top 0.47 per cent in 1953 held 19.0 per cent of the wealth, according to white mortality rate estimates. It is possible then that the fall in the share of the top 0.47 per cent of the population was on the order of 29.2 per cent in 1922 to 19.0 per cent in I $9533^{16}$ See Table 7 .

Table 7. - Share of Personal Sector Total Equity Held by Top 0.47 Per Cent of Persons

\begin{tabular}{ccc}
\hline Year & $\begin{array}{c}\text { Adjusted } \\
\text { Mortality } \\
\text { Rates }\end{array}$ & $\begin{array}{c}\text { White } \\
\text { Mortality } \\
\text { Rates }\end{array}$ \\
\hline$I 922$ & 29.2 & $\ldots$ \\
1953 & 22.5 & 19.0 \\
\hline
\end{tabular}

Changes by Type of Property

Between I922 and I953 the top one per cent of the adult population experienced a decline in share of personal sector total equity and a decline in the share of most types of property. (See Table 8.) Notable exceptions are "stock" and "other bonds," which appear to have changed little in degree of concentration. All studies of stock ownership indicate that this asset is highly concentrated. ${ }^{17}$

${ }^{18}$ The relative fall of ro percentage points is meant to be indicated here. The percentage for 1953 is believed to be substantially too low.

${ }^{17}$ Butters, Thompson and Bollinger give as their best estimate for I949 (based on SRC data, tax return data, and their own field surveys) the following: The upper $3 \%$ of spending units as ranked by income owned $75 \%$ of marketable stock; the top $1 \%, 65 \%$; the top one-half of one per cent slightly over one-half; and the top one-tenth of one per cent, about $35 \%$ of all the marketable stock owned by private investors. They indicate these percentages would be higher if the stock held by personal trust funds were allocated to individuals. (Effects of Taxation: Investments by Individuals, 25, and also Chapters xvI and xvII.) As re- 
Table 8. - Share of Personal Sector Assets and Liabilities, Total Wealth Variant, Held by Top One Per Cent of Adults, by Type of Property, I922, I929, I939, I945, I949, I953 ${ }^{\text {a }}$

\begin{tabular}{|c|c|c|c|c|c|c|}
\hline Type of Property & 1922 & 1929 & 1939 & 1945 & 1949 & 1953 \\
\hline & \multicolumn{6}{|c|}{ Per Cent } \\
\hline Real Estate & I8.0 & 17.3 & I3.7 & I I.I & 10.5 & I 2.5 \\
\hline U.S. Govt. Bonds & $45.0 \mathrm{I}$ & 100.0 & 91.0 & 32.5 & 35.8 & $3 \mathrm{I} .8$ \\
\hline State and Local Bonds & 88.0 & b & h. & & 77.0 & \\
\hline Other Bonds & 69.2 & 82.0 & 75.5 & 78.5 & 78.0 & 77.5 \\
\hline Corporate Stock & $6 r .5$ & 65.6 & 69.0 & 61.7 & 64.9 & 76.0 \\
\hline Cash & . & . & . & 17.0 & I8.9 & 24.5 \\
\hline Mortgages and Notes & . & . & . & 34.7 & 32.0 & 30.5 \\
\hline Cash, Mortgages and Notes & 31.0 & 34.0 & $3 I .5$ & 19.3 & 20.5 & 25.8 \\
\hline Pension and Retirement Fund & ds 8.0 & 8.0 & 6.0 & 5.9 & $5 \cdot 5$ & 5.0 \\
\hline Insurance & $35 \cdot 3$ & 27.0 & I 7.4 & 17.3 & I 5.0 & I 1.5 \\
\hline Miscellaneous & 23.2 & 29.0 & I9.0 & 21.4 & I5.0 & I5.5 \\
\hline Gross Estate & 32.3 & 37.7 & 32.7 & 25.8 & 22.4 & 25.3 \\
\hline Liabilities & 23.8 & 29.0 & 26.5 & 27.0 & I9.0 & 20.0 \\
\hline Economic Estate & 33.9 & 38.8 & 33.8 & 25.7 & 22.8 & 27.4 \\
\hline
\end{tabular}

a Source: Table I and companion unpublished tables, Column I $_{3}$. National balance sheet data used for 1922,1929 , and 1939 are from Goldsmith, A Study of Saving, vol. III; for 1945 , 1949 , and 1953 , from preliminary unpublished tables by the National Bureau of Economic Research.

b In excess of 100 per cent. See text.

However, the unreasonable variation of some of these series, plus the greater than roo per cent figures for state and local bonds, yield a less than convincing picture. It would seem appropriate to review the possible sources of error in the whole process of estimating wealth distribution. The irregularities referred to above could have arisen out of random errors in the sampling process. ${ }^{18}$ For example, the stock fig-

gards a ranking by size of stock-holdings, the $\mathrm{x} \%$ of all spending units that owned $\$ 10,000$ or more of stock accounted for at least two-thirds of the total value of stock reported to the Survey of Consumer Finances (1952 Survey, Federal Reserve Bulletin, September 1952, 985). For one measure of concentration of stock ownership by use of a total wealth ranking, see Goldsmith, A Study of Saving, vol. III, Table W-53. He estimated that in I950 those spending units with $\$ 60,000$ or more of net worth held 76 per cent of corporate stock. The reader is cautioned that rankings by income and wealth are not interchangeable.

${ }^{18}$ The top wealth-holder group held substantially more market value in stocks in 1953 than in 1949 . The aggregate gross estate of decedent top wealth-holders was 36.5 per cent in stock in 1949 , but 40.5 per cent in stock in 1953 . 
ure in one year could be too high because of an unrepresentative age distribution of decedents with large stock holdings. Another possible cause is the selection of mortality rates; we could have the wrong measure of the differential mortality enjoyed by the rich, or, it could be that there are errors in the way property is valued or classified on the estate tax returns. On the other hand, it could be we are confronted with difficulties in the national balance sheet aggregates for the several types of property. ${ }^{19}$ It also is possible that we have double-counted some of the assets in personal trust funds in making adjustments to move from the basic variant to the prime wealth to the total wealth variant of wealth held by top wealth-holders.

All of these considerations urge that the whole of Table 8 be used in evaluating any single figure in it, and that each individual item be treated with caution.

\section{Comparison with England and Wales}

In appraising a given degree of inequality in wealth distribution it is useful to have not only an historical perspective, but a comparison with other national economies. The only other nation for which similar studies have been made is Great Britain. British study of wealth distribution by use of the estate multiplier method goes back to the work of Bernard Mallet in 1908 and includes the later work of G. H. Daniels, H. Campion, and T. Barna. More recently Allan M. Cartter, an American, and Kathleen M. Langley have used this method with British tax data. The British estate tax has had a low filing requirement of $\mathfrak{f}_{\mathrm{I}} \mathrm{OO}$ and hence the estate multiplier method can give a much more nearly complete picture of wealth distribution for Britain than for this country.

${ }^{19}$ It seems probable, for example, that balance sheet difficulties are responsible for the high state and local bonds percentage in 1929 and 1939 . 
Comparison of inequality in the United States and in England and Wales is made possible by our findings as set forth above and those of Langley, who related her own study of postwar distribution to studies by others of earlier periods. Except for the exclusion of life insurance the British data seem to be quite comparable to our own for the United States. Property in trust is treated in the same way in the two countries. Such a comparison yields the finding of much greater inequality in England and Wales.

A similar finding of greater inequality in England appears in a comparison of the I953 parallel surveys of net worth conducted in the two countries. ${ }^{20}$

It would appear that the historical picture of decline in the degree of inequality of wealth distribution is similar in the two countries, at least for the period I922 to I946. (See Chart 6.) However, throughout the whole period the inequality has been considerably greater in England and Wales than in the United States. Mrs. Langley explains the British decline as follows:

The distribution of capital had gradually become more equal during these years. One per cent of the persons aged 25 and over in England and Wales owned 50 per cent of the total capital in 1946-47; in $1936-38$ the percentage was 55 ; in I924-30 I per cent of the persons owned 60 per cent of the total

${ }^{20} \mathrm{~K}$. H. Straw, in discussing the two surveys ("Consumers' Net Worth, the 1953 Savings Survey," Bulletin of Oxford University Institute of Statistics, February I956, Table II, 4) supplies us with some clues as to why the difference in inequality may prevail. In Great Britain $\mathrm{I} 6$ per cent of the population is over 60 years of age, while the comparable figure for the United States is I2 per cent. In the United States, 9 per cent of the spending units are headed by farm operators while only I per cent of the British income units are so headed. In the United States half the spending units own their own homes, while in Britain only 27 per cent of the primary income units own their homes. Also see Harold Lydall and J. B. Lansing, "A Comparison of Distribution of Personal Income and Wealth in the United States and Great Britain," American Economic Review, x工Ix (March I 959 ), 43-67. 
Chart 6. - Upper Section of Lorenz Curves of the Shares of Personal Sector Gross Estate Held by Top Percentiles of Adults, England and Wales and the United States, Selected Years, I9I I-I 953
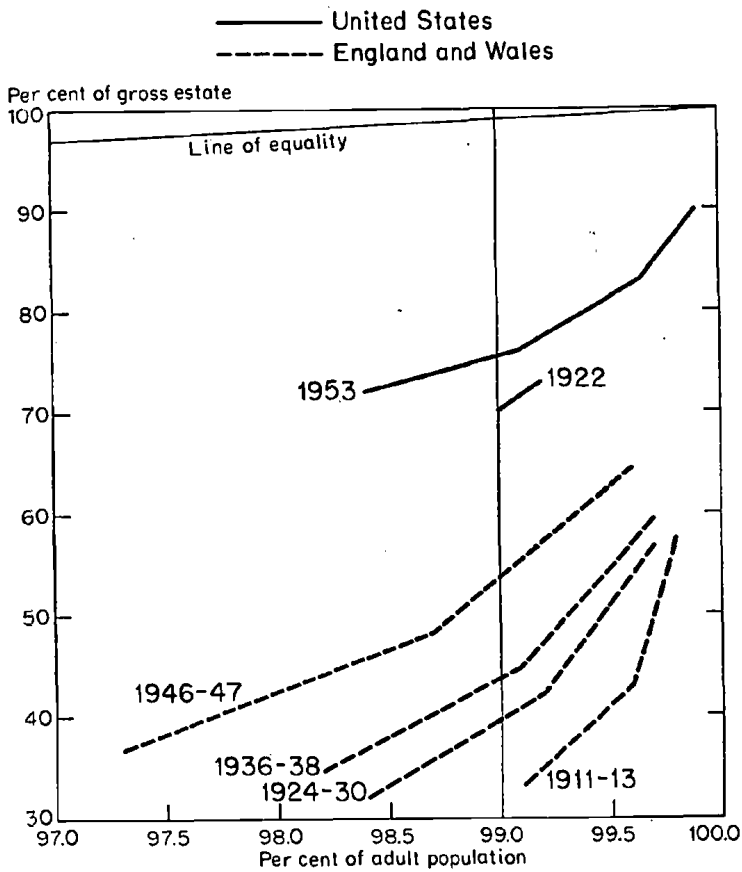

Source: For England and Wales, Kathleen M. Langley, "The Distribution of Capital in Private Hands in 1936-38 and 1946-47" (Part II), Bulletin of the Oxford University Institute of Statistics, February 1951, Table XVB, 46. For the United States, Table 3, infra.

capital; while in I9II-I3, I per cent of the persons owned 70 per cent of the total capital. The scale of wealth had changed from that of I9II-I 3 ; there were more people in each of the groups over $\mathfrak{E}_{\mathrm{I}} \mathrm{Oo}$. Inequality had lessened by I946-47 but capital was still unequally distributed. Ten per cent of the total number of persons aged 25 and over owned 80 per cent of the total capital in this period while sixty-one per cent of the adult population owned 5 per cent of the total capital in $1946-47 .^{21}$

\section{Summary}

Thirty per cent of the assets and equities of the personal sector of the economy in 1953 is

${ }^{\text {x1 }}$ Langley, "The Distribution of Capital in Private Hands," op. cit., 47. 
assignable to the top wealth-holders, i.e., persons with $\$ 60,000$ or more of estate tax wealth, who were I.6 per cent of the total adult population that year. The top group owned at least 80 per cent of the corporate stock held in the personal sector, virtually all of the state and local government bonds, nearly 90 per cent of corporate bonds, and between ro and 35 per cent of each other type of property held in the personal sector in that year. These relationships are quite close to those found by the Survey of Consumer Finances for the same year.

The top wealth-holder group, defined according to estate-tax requirements, has varied in number and per cent of the total population over the years. Also, their share of total wealth has varied. It appears, however, that the degree of inequality in wealth-holding increased from 1922 to 1929 , fell to below the pre-1929 level in the I930's, fell still more during the war and to 1949 and increased from I 949 to I 956 . However, the degree of inequality was considerably lower in $195^{6}$ than in either 1929 or 1922 .

To make a comparison of degrees of wealth concentration it is convenient to consider a constant percentage of the total adult population. The top one per cent of adults held 32 per cent of personal sector equity in 1922,36 per cent in 1929,31 per cent in I939, and 24 per cent in 1953. It is probable that the decline in inequality among individual wealth-holders is greater than would be found if families were considered as the wealth-holding units, since it is apparent from the data that married women are an increasing part of the top wealth-holder group. Converting to a measure of "adults less married women" suggests that half the percentage decline found for individuals between 1922 and I953 would disappear on a family basis (Table 9).

In these figures two types of error in estimation are likely to offset each other in some de- 
Table 9. - Share of Personal Sector Wealth (Equi-

TY) Held by Top Wealth-Holders IN I922 AND 1953

\begin{tabular}{lccc}
\hline$=$ & $\begin{array}{c}\text { Top I Per Cent } \\
\text { of Adults }\end{array}$ & $\begin{array}{c}\text { Top I/2 Per Cent } \\
\text { of All Persons }\end{array}$ & $\begin{array}{c}\text { Top a Per Cent } \\
\text { of Families a }\end{array}$ \\
\hline I922 & 31.6 & 29.8 & 33.0 \\
I953 & 23.6 & 22.7 & 29.0 \\
\hline
\end{tabular}

n Families here defined as all adults less married females.

gree. On the one hand, the selection of mortality rates tends to understate the decline in inequality. On the other hand, the differences over time in completeness of reporting personal sector wealth and of estate tax wealth may tend to overstatement of the decline. It is difficult to imagine any combination of errors which would yield a result of increasing concentration over time. Interestingly, the conclusions about changes in concentration of wealth over the years are not affected by selection of one or another variant of wealth.

A leading exception to the general picture of declining concentration is corporate stock. This particular type of asset appears to have become no less concentrated in ownership over time.

Inequality of wealth distribution is considerably greater in Great Britain than in the United States, but a pattern of similar historical decline in inequality is observable in the two countries.

It helps to place these findings in perspective to compare them with Simon Kuznets' findings in Shares of Upper Income Groups in Income and Savings (National Bureau of Economic Research, 1953). He traced changes in the shares of the upper one and five per cent of persons in a per capita distribution from 1913 to 1948 and found that the top 5 per cent's share of basic variant income had a rather narrow range of movement during the period 1919-1938, with no perceptible and sustained change. However, he found that "From 1939 to 1944 it dropped from 23.7 to $r 6.8$ per cent - almost 7 percent- 
age points in five years; and in 1947 and 1948 its level was only slightly higher - I 7.6 and I 7.8 per cent respectively. During the last decade, then, the share of the top 5 per cent declined about a quarter." ${ }^{22}$ The fall for the top I per cent was from I 2 per cent in 1939 and I 940 to about $81 / 2$ per cent in 1947 and 1948 . In the disposable income variant the top five per cent's share fell by well over three-tenths, from 27.1 to 17.9 per cent.

Our finding that the share of wealth held by the top two per cent of families fell from about 33 per cent to 29 per cent from 1922 to 1953 , or by about one-eighth, would seem to be not incompatible with Kuznets' findings ${ }^{23}$ and with the general belief that there has been some lessening of economic inequality in the United States in recent decades. Wealth distribution appears to have changed less than income distribution during this period.

${ }^{22}$ Ibid., xxxvii.

${ }^{23}$ Kuznets' per capita distribution of income should not be confused with a per earner distribution. In the former family income is divided by number of family members to obtain an array of families (or individuals) by per.capita income. Since our wealth-holder data are not calculated on a per capita basis we cannot make a direct comparison with Kuznets' findings on income. Our estimates of the distribution of wealth by families seem to be conceptually closest to Kuznets' per capita procedure. 


\section{How to Obtain National Bureau Publications}

The National Bureau of Economic Research is a nonprofit membership corporation organized to make impartial studies in economic science.

Its books are published and distributed by the Princeton University Press; its Occasional Papers and Technical Papers are published and distributed by the National Bureau itself.

The National Bureau's publications may be obtained either on subscription or by purchase.

Contributing subscription rates, effective January 1, 1959, are the standard rate of $\$ 75$ a year and the educational rate of $\$ 35$ a year. The educational rate is open to teachers, students, other individuals, and libraries of recognized educational institutions, and to public libraries; and to individual members and libraries of scientific societies or of private nonprofit research agencies.

Contributors of these amounts or more are entitled to receive a complimentary copy of each current publication-books, Occasional Papers, Technical Papers, and the Annual Report - in advance of release to the public. In addition, contributors are entitled to a one-third discount on all National Bureau publications purchased.

The associate subscription rate is $\$ 10$. A contributor of this amount receives a complimentary copy of each current Occasional Paper, Technical Paper, and the Annual Report, and is entitled to a one-third discount on all publications purchased. Only the following are eligible to become associates: teachers, students, other individuals, and libraries of recognized educational institutions, and public libraries; and individual members and libraries of scientific societies or of private nonprofit research agencies.

The subscription rate of Occasional Papers is $\$ 4$ for five issues. A contributor of $\$ 4$ receives the next five Occasional Papers (or any Technical Papers issued during this period may be substituted) and the Annual Report.

Contributions to the National Bureau are deductible in calculating federal income taxes.

NONCONTRIBUTORS: Order Books from

Princeton University Press, Princeton, New Jersey

NONCONTRIBUTORS:

Order Papers and request the Annual Report from:
CONTRIBUTORS:

Order all books and Papers and request the Annual Report from:

NATIONAL BUREAU OF ECONOMIC RESEARCH, INC. 261 Madison Avenue New York 16, N. Y. 
Changes in the Share of Wealth Held by Top Weslth-Bolders, $1922-1956$

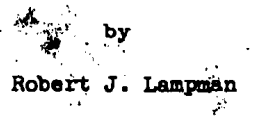

\section{BRRATA}

Dates in titles of charts and tables should read 1922-1956 for the following:

$$
\begin{array}{ll}
\text { Chart } 2 & \text { (Page 15) } \\
\text { Table } 3 & \text { (Page 16) } \\
\text { Table } 4 & \text { (Page 18) } \\
\text { Chart } 5 & \text { (Page 24) }
\end{array}
$$

\section{(Page 21)}

Table 5 - Share of Top Groups of Wealth-Holders (Shown as Per Cent of Total Adult Population) in Personal Sector Total Bquity (Basic Varisnt), Selected Years, 1922-1956

Per cent of

Population

Aged 20 Years and over 1922 $1929 \quad 1933$ 1939 1945 1949 $1953 \quad 1954$ 1956

Top 0.44 $29.0 \quad 23.3$

18.3

0.79

29.2

$22: 3$

0.89

29.1

23.3

0.98

23.2

24.1

1.26

22.7

26.4

1.57

28.4 28.0

1.60

28.5

1.90

Top 1.00

31.6 36.3

$28.3 \quad 30.6$

23.3

20.8

24.2

24.0

33.0

Source: Table 3, columns 15 and 16. Percentages for top one per cent of adults, shown in last row above, are derived from chart 4 by extension of lines from known points except for 1953 .

\section{(Page 31)}

Table 9 - Share of Personal Sector Wealth (Bquity) Beld by Top Wealth-Holders in 1922 and 1953

Year Top 1 Pèr Cent of Adults Top $1 / 2$ Per Cent
of All Persons

31.6
24.2 Top 2 Per Cent 1922

31.6
24.2 29.8

22.7

$$
\text { of Families }
$$

33.0

29.0 


$$
2,005,961
$$

National. Bureau_of_Economic_Reseanch,-_Inc

\section{Lampman, Robert $\mathbf{J}$}

Clianges in the,shinre of wenlth held by top wealth-holders,

$$
\text { 1922-19f6. [ Yow York, National Burenu of }
$$

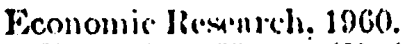

32 p. Illis. 24 cli. (Xutionnl Bureau of Economic Rosearch. Occasional papri. 71)

"lleprinind floulu the November $10 j 0$ lssue of the Revlew of econoroles and stutistick."

1. Wulth-l:S. I. Title.

III.N2432 no. 71 339.410973 $50-12561$

MATERIAL SUBMITTED BY PUBLISHER.

$$
2,005,961
$$

National-nureau-of-Economi-c-Research-Inc-

\section{Lampman, Robert J}

Chinges in theshne of wenlth held by top wealth-holders, 1??2-1956. Fow York National Burenu of

Fconomic limintis 1960.

32 n. Illus. 23 cuil. (Xutlonal Bureau of Economlc Research. Occasional mine 71 )

"Reprinfind frim the Norember 1050 Issue of the Review of econombeg und stutistics,"

1. Wealth-l: s. r. Title.

II11.N2432 no. 71

339.410973

$50-12561$

MATERIAL SUBMITTED BY PUBLISHER. 